\title{
Activation of Apoptosis and Autophagy by Gratiola Officinalis Extract in Human Tumor Cell Lines
}

\author{
Natal'ya V. Polukonova1, Maria A. Baryshnikova², Dmitry A. Khochankov², \\ Evgeniya V. Stepanova ${ }^{2}$, Eliso S. Solomko ${ }^{2}$, Anna V. Polukonova ${ }^{1}$, Dmitrij A. Mudrak ${ }^{1}$, \\ Artem M. Mylnikov ${ }^{1}$, Alla B. Bucharskaya ${ }^{1}$, Galina N. Maslyakova ${ }^{1}$, and Nikita A. Navolokin ${ }^{1 *}$ \\ ${ }^{1}$ Saratov State Medical University named after V. I. Razumovsky, 112 Bolshaya Kazachya str., Saratov 410012, \\ Russian Federation \\ ${ }^{2}$ National Medical Research Center of Oncology named after N. N. Blokhin, 24 Kashirskoe highway, Moscow 115478, \\ Russian Federation
}

* e-mail: nik-navolokin@yandex.ru

\begin{abstract}
The problem of creating antitumor drugs with new mechanisms of action that predominantly induce apoptosis is still topical. The extract of Gratiola officinalis is a potential antitumor agent containing mainly flavonoids. The aim of this research is to study the effects of Gratiola officinalis extract on activation of apoptosis and autophagy in breast adenocarcinoma SK-BR-3 and kidney carcinoma A-498 lines. Apoptotic activity of the extract was studied by flow cytofluorometry using Hoechst stain and double staining with annexin V plus propidium iodide. There was $96.3 \%$ of cells in SK-BR-3 culture in late apoptosis phase detected by flow cytofluorometry method at the extract concentration of $0.88 \mathrm{mg} / \mathrm{ml}, 86.3 \%$ of cells were in apoptosis by Hoechst stain. The concentration of $0.82 \mathrm{mg} / \mathrm{ml}$ caused apoptosis in half of the cells. The extract has cytoprotective activity at low concentration $(0.0352 \mathrm{mg} / \mathrm{ml})$. The cytoprotection mechanism is realized through the activation of autophagy. The maximum number of autophagosomes in kidney carcinoma cells is observed at the extract concentration of $0.056 \mathrm{mg} / \mathrm{ml}$. Thus, Gratiola officinalis extract is able to block cytoprotective autophagy with increasing the extract concentration and to activate apoptosis in $85 \%$ of tumor cells. Detailed research should be continued to understand the mechanisms of antitumor activity of Gratiola officinalis extract. (C) 2021 Journal of Biomedical Photonics \& Engineering.
\end{abstract}

Keywords: autophagy; apoptosis; antitumor agents; Gratiola officinalis; antitumor agents; tumor; flavonoids.

Paper \#3449 received 1 Aug 2021; revised manuscript received 7 Oct 2021; accepted for publication 11 Oct 2021; published online 10 Nov 2021. doi: 10.18287/JBPE21.07.040307.

\section{Introduction}

High biological and toxic activity of antitumor agents determines their damaging effect not only on tumor cells, but also on healthy cells. Antitumor agents cause hematopoietic disorders, including sterilization, growth retardation in children, deterioration of wound healing, hair loss and teratogenic effect $[1,2]$.

Plant derived drugs, namely alkylating agents (antimetabolites, antitumor antibiotics, herbal preparations, hormones and their antagonists) are the main groups of antitumor agents. The alkaloids of various plants are most commonly used as antitumor agents. These compounds act as mitotic poisons or as topoisomerase inhibitors. They can stop the cell cycle in M-phase stages or in S- and G2-periods. In the tumor, they also may cause damage, necrotic changes, cell polymorphism, fibrosis, and hyalinosis [3].

A number of flavones and flavonols have been found to possess antitumor activities [4]. The property of bioflavonoids to enhance the effectiveness of cytostatic therapy due to the weakening of its toxic effect on healthy cells has been studied, and the direct ability of Wogonin flavonoid and structurally related natural flavones, for example, apigenin, chrysin and luteolin to activate apoptosis in tumor cells has been revealed [5-6]. 
Wogonin, one of the active flavones of the most popular Chinese herbal remedy Huang-Qin (Scutellaria baicalensis Georgi), induces apoptosis in a wide spectrum of human tumor cells in vitro and inhibits tumor growth in vivo in different mouse tumor models [7]. In addition, Scutellaria extracts were successfully tested in patients with advanced breast cancer in early clinical trials $[6,8,9]$. Importantly, at doses lethal to tumor cells, wogonin showed no or little toxicity for normal cells and had also no obvious toxicity in animals [10].

However, no one had previously conducted a comprehensive study of morphological changes in a tumor under the influence of flavonoids. Data on the morphological changes in tumor cells under the influence of flavonoids would open up the prospect of their further active screening as potential antitumor agents.

For this study, we selected the plant Gratiola officinalis L. The plant is harvested whilst in flower in the summer and dried for later use $[11,12]$. It is used in the herbal medicines for the treatment of a variety of ailments like scrofula, cystitis, colic, certain stomach and menstrual disorder, skin and liver diseases as well as enlargement of the spleen, dropsy, jaundice, intestinal worms, etc. The dried top of the G. officinalis has diuretic and emetic effect. G. officinalis is also used as biostimulating medicine in hematopoietic, liver and respiratory disorders in human [13-15]. Side effects of its overuse include nausea, acrid poisoning, nymphomania, leanliness, abortion, kidney damage and bowel hemorrhage $[12,16,17]$. The presence of alkaloids, flavonoids, saponins, glycoside-like substances, coumarin derivatives, mannitol and betulinic acid in G. officinalis has been found in studies $[13,18,19]$. G. officinalis also contains the following substances: gratiogenin, 16-hydroxygratiogenin, cucurbitacins-E and I, glycosides gratiogenin-3beta-D-glucoside, gratioside, elaterinide, lignans, which have many medicinal uses. Caffeic acid glycoside esters, verbascoside and arenarioside, have been isolated from G. officinalis [20]. Caffeic acid has been shown to inhibit carcinogenesis. Caffeic acid also shows immunomodulatory and antiinflammatory activity [13].

One of the chemotypes is characterized by the production of 8-hydroxylated flavone O-glycosides including the new plant substances 8-hydroxychrysoeriol 8-Oglucuronide, hypolaetin 7-O-sophoroside, 8-hydroxychrysoeriol 7-O-sophoroside, and isoscutellarein 8-O-sophoroside [21, 22]. According to data of other researches, new flavonoid named ligniside and C-glycosyl derivatives were also extracted from G. officinalis [23, 24]. Apigenin, 4, 5, 7- trihydroxyflavone $\quad\left(\mathrm{C}_{15} \mathrm{H}_{10} \mathrm{O}_{5}\right), \quad$ Cosmosiin $\left(\mathrm{C}_{21} \mathrm{H}_{20} \mathrm{O}_{10}\right)$, one form of saponaretin $\left(\mathrm{C}_{21} \mathrm{H}_{20} \mathrm{O}_{10}\right)$, and a form of vitexin $\left(\mathrm{C}_{21} \mathrm{H}_{20} \mathrm{O}_{10}\right)$ were among the nine found [25].

The extract of $G$. officinalis obtained us by the author's method contains flavonoids and has no toxic effects [26]. Earlier, we revealed antioxidant, antitumor, antiexical and immunomodulatory properties of
G. officinalis L. extract in laboratory animals with transplanted tumors [27-36]. This extract also has antituberculous, anti-inflammatory, antipyretic, and antimicrobial activity, which indicates its polyvalent action [29, 31].

The aim of this research was to study the activation of autophagy and apoptosis in human tumor cell lines breast adenocarcinoma SK-BR-3 and kidney carcinoma A-498 under the influence of Gratiola officinalis extract.

\section{Material and methods}

Gratiola officinalis extract was obtained by the author's method from herbal raw materials, which was collected on the Volga River island near the village of Chardym (Saratov region) [26, 27, 35].

According to gas chromato-mass spectrometry, chemical analysis of this extract showed the presence of the following substances: quercetin; 4-vinyl-2methoxyphenol; 2,3-dihydroxy-3,5-dihydroxy-6methyl-4H-pyran-4-on; 2,3-dihydrobenzofuran; 3-furancarboxylic acid; 5-hydroxymethyl-2-furaldehyde; ethyl-4-riboside-propylphenol; pyrocatechin; L-luxose(pentose); 6-deoxyhexoses of L-galactose; ethyl ester of benzoylacetic acid; palmitic acid; homovanilic acid; glucose; 1,4-anhydro-d-mannitol; benzoic acid; Gallic acid [26, 35].

Dried extract mixed with water and ethyl alcohol in any ratio has a yellow-brown color. The average value of quercetin in this extract is specified in the calibration schedule using the standard sample of quercetin (Sigma, $98 \%$ ) amounts to $0.66 \%$. The amount of quercetin in the dry residue of the extractive substances from $10 \mathrm{~g}$ of dry Gratiola officinalis grass, established by liquid chromatography (HPLC), was $350 \mu \mathrm{g}$.

The authenticity of the extract of Gratiola officinalis is confirmed by the qualitative reactions with the crystalline magnesium reagent and Wagner-Bouchard. Qualitative reactions indicate the presence of bioflavonoids and the absence of alkaloids in the extract.

We used the concentration of the extract at which its apoptotic effect and the ability to cause (or not to cause) autophagy were obvious, preliminary work on the analysis and selection of extract concentrations was carried out earlier [36].

\subsection{Cell line}

The following cultures of human tumor cells from the Bank of cell lines of the National Medical Research Center of Oncology named after N. N. Blokhin were used in the studies: human breast carcinoma SK-BR-3, human kidney carcinoma A-498. Studies on cell cultures were conducted at the Core Facilities of Saratov State Medical University named after V. I. Razumovsky.

Cell lines were cultured at $37{ }^{\circ} \mathrm{C}$ in an atmosphere of $5 \% \mathrm{CO}_{2}$ in a complete nutrient medium RPMI-1640 (Paneco, Russia): 10\% embryonic calf serum (TPP, HyClone, USA); 2 mg/ml glutamine (Paneco, Russia), $50 \mathrm{mg} / \mathrm{ml}$ penicillin streptomycin (Paneco, Russia). 
The cells were grown on the slides up to $70 \%$ of the monolayer. After incubation with the test extracts for $24 \mathrm{~h}$, cells were fixed in alcohol and acetone, then they were stained with Hoechst 33258 dye $(1 \mu \mathrm{g} / \mathrm{ml}$, PanEco, Russia). Cells were covered with coverslips using fluorescent mounting medium (Dako, Denmark), the samples were analyzed by a Nikon $80 \mathrm{i}$ fluorescence microscope (Japan) at 435-485nm.

The following parameters were used in the analysis of cells stained with Hoechst 33258: average number of living cells (ANLC) in the field of view; culture growth activity is ratio of average number of exposed cells in the field of view to the average number of all cells in the field of view in control samples; absolute number of mitoses in the field of view; percentage of cells in mitosis (total number of cells); mitotic activity index is ratio of number of cells in mitotic stages to the total number of cells in the field of view, multiplied by 100; absolute number of apoptosis in the field of view; apoptotic activity index is the ratio of cells in apoptosis to the total number of cells in the field of view, multiplied by 100; the ratio of cells with pycnosis to the total number of cells with signs of apoptosis (\%); the ratio of apoptotic bodies to the total number of cells with apoptotic signs (\%).

The cells in each group were counted in at least 10 fields of view at $200 \times$ magnification.

\subsection{Determination of apoptosis by double staining with Annexin and Propidium iodide}

Apoptosis induction was studied after incubation of cell lines with Gratiola officinalis extract at a concentration of $0.88 \mathrm{mg} / \mathrm{ml}$ for $24 \mathrm{~h}$. The study was carried out using the Annexin-V FITC Apoptosis Kit (Invitrogen). Annexin-V binds to phosphatidylserine, which exits the cell membrane in the early stage of apoptosis. Propidium iodide (PI) binds to the DNA of destroyed cells and it is a marker of late-stage apoptosis or necrosis.

To set the reaction, the cells were removed, washed in PBS and resuspended in an Annex-binding buffer in the amount of 1 million cells $/ \mathrm{ml}$, then $100 \mu \mathrm{l}$ cells were transferred to tubes containing $5 \mu \mathrm{l}$ Annexin-V-FITC and $5 \mu \mathrm{PI}$ and incubated at room temperature in the dark for $15 \mathrm{~min}$.

Then $400 \mu 1$ of the annexin-binding buffer was added and cells were counted on a flow cytometry (FACS Canto II, Becton Dickenson).

\subsection{Determination of the induction of autophagy}

Determination of the induction of autophagy was performed on the Muse cell analyzer (Millipore, Sigma) with the Muse reagents Autophagy LC3-Antibody Based Kit (Abcam, USA).

Kidney carcinoma cell lines were treated with G. officinalis extract in different concentrations at twofold dilutions, starting at $3.6 \mathrm{mg} / \mathrm{ml}$ for a day: $3.6 ; 1.8$;
$0.9 ; 0.45 ; 0.225 ; 0.113 ; 0.056 ; 0.028 ; 0.014 ; 0.007$; $0.004 \mathrm{mg} / \mathrm{ml}$. Cells were stained for LC3B protein (Muse Autophagy LC3-Antibody Based Kit (Millipore Sigma)), cell nuclei were stained with Hoechst 33258 dye. As a result of staining with LC3-Antibody reagents, cells acquired a dull red glow when autophagosomes formed, and a bright scarlet glow when autophagosomes bound to lysosomes and the digestion started. The indicators were compared: Mean Autophagy Intensity and Autophagy Induction Ratio at different Concentration of extract. Indicators were calculated automatically on Millipore Sigma.

\subsection{Statistical analysis}

The normality of the group distribution was tested using the Shapiro-Wilk criterion. The Cramer-Welch criterion (T) was used to compare the obtained mean values, in which the difference of the arithmetic mean of the two samples (control and experimental) is divided by the natural estimate of the standard deviation of this difference. With this method, the difference in the mean is determined with a $95 \%$ probability at $\mathrm{T} \geq 1.96$ at a significance level of $\mathrm{p}<0.05$. All statistical analyses are performed by using STATISTICA 10.0 Enterprise software.

\section{Results and discussion}

\subsection{Analysis of apoptotic activity in tumor cells of lines $A-498$ and $S K-B R-3$ using double staining with annexin $V$ and propidium iodium}

Cell lines were incubated with Gratiola officinalis extract at a concentration of $0.88 \mathrm{mg} / \mathrm{ml}$. Annexin V labelled with FITC, stained cells in early apoptosis phase. Double staining with annexin and propidium iodide indicated the presence of late apoptosis phase in cells.

As a result, the Gratiola officinalis extract showed antitumor activity against all tested human tumor cells (Fig. 1).

An increase in the number of apoptotic cells was observed in all studied human tumor cell lines under the action of $G$. officinalis extract at a concentration of $0.88 \mathrm{mg} / \mathrm{ml}$, in contrast to the control (Fig. 1).

After one day, mainly cells in late apoptosis phase were detected: $96.3 \pm 2.7 \%$ of SK-BR-3 breast carcinoma cells and $89.5 \pm 3.3 \%$ of A-498 kidney carcinoma cells at tested concentration of $G$. officinalis extract (Fig. 1).

However, the A-498 kidney carcinoma culture was also characterized by an increase in the number of cells in early apoptosis phase to $6.4 \pm 1.8 \%$. These results confirm the fact of varying degrees of sensitivity of tumor cells to the extract, but all studied cultures were susceptible to the effects of $G$. officinalis extract, which caused the activation of apoptosis. 


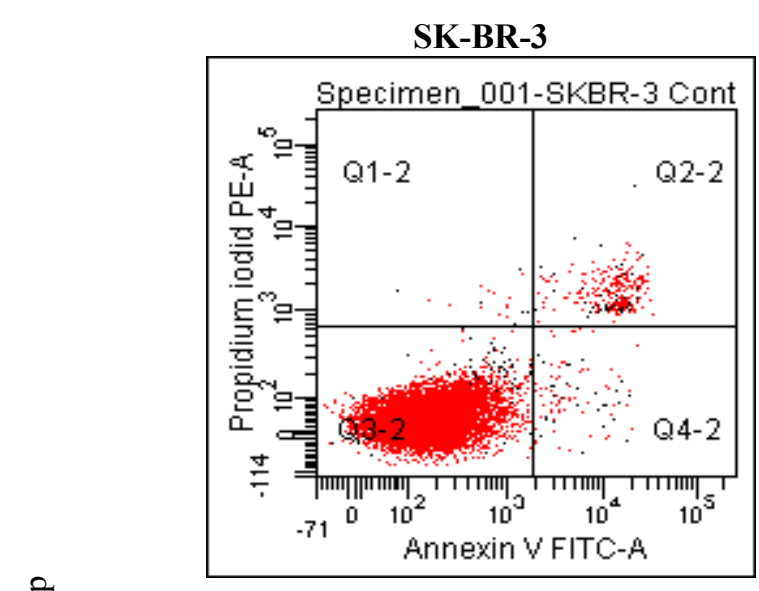

Square Q3 - Living cell $\left(\mathrm{AnV}^{-} / \mathrm{PI}^{-}\right), 96.7 \%$;

Square Q4 - Early apoptotic cells $\left(\mathrm{AnV}^{+} / \mathrm{PI}^{-}\right), 0.9 \%$;

Square Q2 - Late apoptotic cells $\left(\mathrm{AnV}^{+} / \mathrm{PI}^{+}\right), 2.3 \%$;

Square Q1 - Necrotic cells $\left(\mathrm{AnV}^{-} / \mathrm{PI}^{+}\right), 0.2 \%$

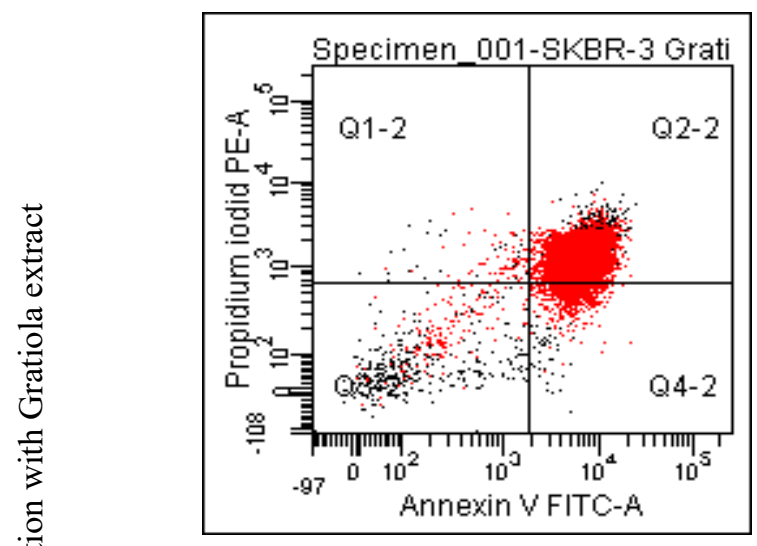

Square Q3 - Living cell $\left(\mathrm{AnV}^{-} / \mathrm{PI}^{-}\right), 1.3 \%$;

Square Q4 - Early apoptotic cells $\left(\mathrm{AnV}^{+} / \mathrm{PI}^{-}\right), 1.5 \%$;

S Square Q2 - Late apoptotic cells $\left(\mathrm{AnV}^{+} / \mathrm{PI}^{+}\right), 96.3 \%$;

Square Q1 - Necrotic cells $\left(\mathrm{AnV}^{-} / \mathrm{PI}^{+}\right), 0.9 \%$

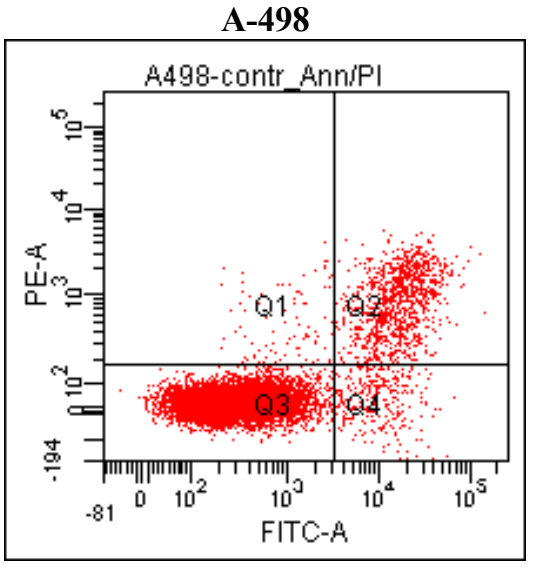

Square Q3 - Living cell $\left(\mathrm{AnV}^{-} / \mathrm{PI}^{-}\right), 82.9 \%$;

Square Q4 - Early apoptotic cells $\left(\mathrm{AnV}^{+} / \mathrm{PI}^{-}\right), 3.8 \%$;

Square Q2 - Late apoptotic cells $\left(\mathrm{AnV}^{+} / \mathrm{PI}^{+}\right), 12.2 \%$;

Square Q1 - Necrotic cells $\left(\mathrm{AnV}^{-} / \mathrm{PI}^{+}\right), 1.1 \%$

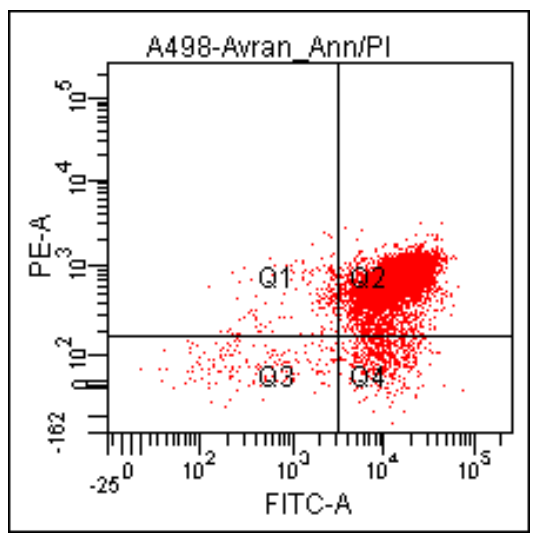

Square Q3 - Living cell $\left(\mathrm{AnV}^{-} / \mathrm{PI}^{-}\right), 2.1 \%$;

Square Q4 - Early apoptotic cells $\left(\mathrm{AnV}^{+} / \mathrm{PI}^{-}\right), 6.4 \%$;

Square Q2 - Late apoptotic cells $\left(\mathrm{AnV}^{+} / \mathrm{PI}^{+}\right), 89.5 \%$;

Square Q1 - Necrotic cells $\left(\mathrm{AnV}^{-} / \mathrm{PI}^{+}\right), 2.0 \%$

Fig. 1 Percentage distribution of tumor cells after incubation with Gratiola officinalis extract and control group according to flow cytometry. Square Q3 - Living cell, Square Q4 - Early apoptotic cells, Square Q2 - Late apoptotic cells, Square Q1 Necrotic cells. Control: a) SK-BR-3, b) A-498. Gratiola officinalis extract: c) SK-BR-3; d) A-498.

However, the A-498 kidney carcinoma culture was also characterized by an increase in the number of cells in early apoptosis phase to $6.4 \pm 1.8 \%$. These results confirm the fact of varying degrees of sensitivity of tumor cells to the extract, but all studied cultures were susceptible to the effects of G. officinalis extract, which caused the activation of apoptosis.

\subsection{Analysis of apoptotic activity at different extract concentrations in the cell line of breast carcinoma (SK-BR-3) by immunocytochemical method}

In the control of cell culture SK-BR-3 in a day the average number of living cells (ANLC) was 365 cells, $0.68 \%$ of which were at the stages of metaphase, anaphase and telophase of mitosis and $0.56 \%$ in the form of apoptotic cells. In this case, the chromatin of the cell nuclei was not intensely colored (Fig. 2).

After incubation with Gratiola officinalis extract in a concentration of $0.0352 \mathrm{mg} / \mathrm{ml}$, an increase of 1.2 times the ANLC was observed compared to the control. The data showed an increase in proliferative activity, apparently due to the cytoprotective effect of the extract. At the same time, the number of cells in mitosis at the stage of metaphase, anaphase and telophase did not differ from the control (Fig. 2, Table 1).

The number of cells in apoptosis increased by 3.5 times compared to the control. At the same time, all cells with signs of apoptosis were represented by apoptotic corpuscles (Table 1, Fig. 2). 
Table 1 Comparison of viability and death of SK-BR-3 tumor cells after extract exposure.

\begin{tabular}{|c|c|c|c|c|c|c|}
\hline \multirow{2}{*}{ Groups } & \multirow{2}{*}{ ANLC } & \multirow{2}{*}{$\begin{array}{l}\text { Index of } \\
\text { proliferation }\end{array}$} & \multirow{2}{*}{$\begin{array}{l}\text { Fraction of } \\
\text { metaphase, } \\
\text { anaphase and } \\
\text { telophase, \% }\end{array}$} & \multirow{2}{*}{$\begin{array}{l}\text { Fraction of cells } \\
\text { in apoptosis (in } \\
\text { field of view), \% }\end{array}$} & \multicolumn{2}{|c|}{$\begin{array}{l}\text { Fraction of cells in } \\
\text { apoptosis } \\
\text { (in the field of view), \% }\end{array}$} \\
\hline & & & & & $\begin{array}{l}\text { with } \\
\text { pyknosis }\end{array}$ & $\begin{array}{l}\text { with } \\
\text { apoptotic } \\
\text { cells }\end{array}$ \\
\hline Control & $365 \pm 24.59$ & - & $0.68 \pm 0.13$ & $0.56 \pm 3$ & 0 & 0 \\
\hline \multicolumn{7}{|c|}{ after Gratiola extract exposure } \\
\hline $0.0352 \mathrm{mg} / \mathrm{ml}$ & $454 \pm 14.9^{*}$ & 1.24 & $0.56 \pm 0.14$ & $1.96 \pm 0.37 * *$ & 0 & 100 \\
\hline $0.176 \mathrm{mg} \mathrm{ml}$ & $354.6 \pm 4.2$ & 0.97 & $0.46 \pm 0.15$ & $2.3 \pm 0.04^{*}$ & 25 & 75 \\
\hline $0.88 \mathrm{mg} / \mathrm{ml}$ & $236.6 \pm 7.8^{* * *}$ & 0.65 & $0 * * *$ & $86.3 \pm 1.4^{* * *}$ & 100 & 0 \\
\hline
\end{tabular}

Note: proliferation index is the ratio of ANLC after extract exposure to ANLC in the control. Differences are significant between values of experimental and control groups at $(*) p<0.05 ;\left(^{* *}\right) p<0.005 ;(* *) p<0.001$.
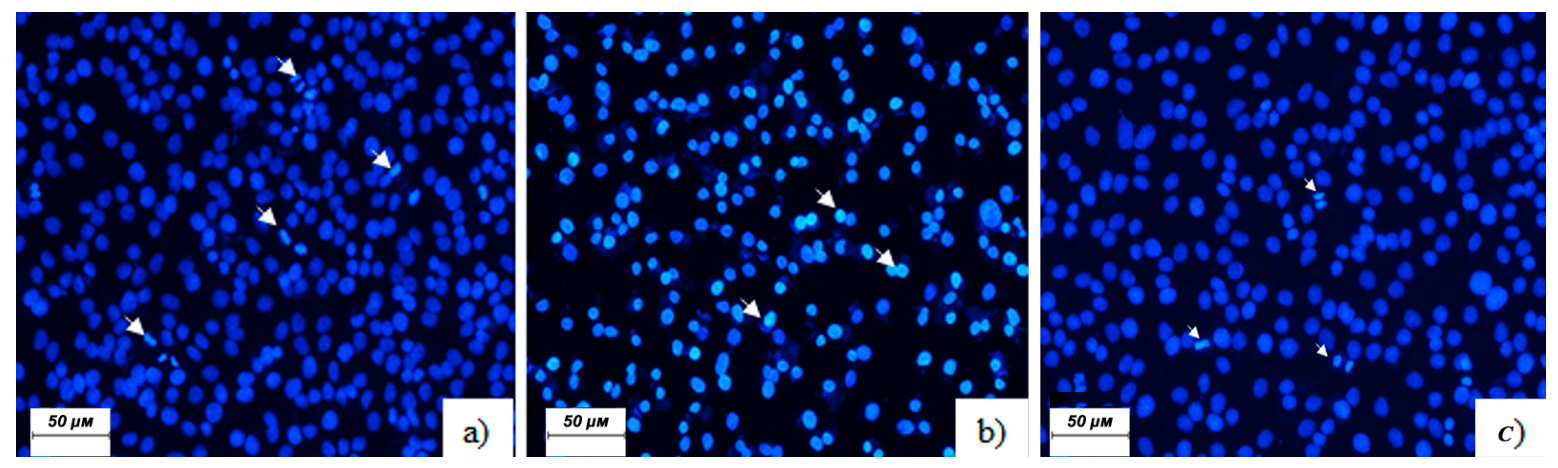

Fig. 2 The breast carcinoma cell line SK-BR-3 after incubation with Gratiola extract at a concentration of: a) $0.0352 \mathrm{mg} / \mathrm{ml}$. The cells in process of mitosis are marked with the arrows: b) $0.88 \mathrm{mg} / \mathrm{ml}$. The nuclei in condition of a pyknosis are marked with the arrows; c) control - the cells in process of mitosis are marked with the arrows. The fluorescence mode at $435-485 \mathrm{~nm}$, the color of the dye Hoechst 33258. Magnification 200×.

At exposure of Gratiola officinalis extract in a concentration of $0.176 \mathrm{mg} / \mathrm{ml}$, ANLC and the number of cells in mitosis (at the stages of metaphase, anaphase and telophase) did not differ from the control (Table 1). The number of cells with signs of apoptosis increased by 1.6 times, most of which were detected in the form of apoptotic cells $(75 \%)$, the remaining cells are with nuclear pyknosis $(25 \%)$, which was expressed in bright staining of the nuclei.

At incubation with Gratiola officinalis extract in a concentration of $0.88 \mathrm{mg} / \mathrm{ml}$ (Fig. 2) there was a 35\% decrease in ANLC compared to control and no cells at the stages of metaphase, anaphase and telophase of mitosis (Table 1). Such data indicate the presence of cytostatic activity in the extract, due to the lack of cytoprotective action in high concentrations. The vast majority of cells (86\%) were in apoptosis; namely, with condensed brightly colored chromatin of the nucleus (Fig. 2, Table 1). Such results indicated the presence of expressed apoptotic activity in the extract.

The half of the cells with signs of apoptosis (AC50) were determined per day in comparison with the control at $0.815 \mathrm{mg} / \mathrm{ml}$ concentration of Gratiola officinalis extract.
Thus, Gratiola officinalis extract in all concentrations had apoptotic activity against breast carcinoma cells SKBR-3, which was consistent with the data of flow cytometry. At low concentrations $(0.0352 \mathrm{mg} / \mathrm{ml})$ extract had cytoprotective activity, which was concentrationdependent.

At double staining with Annex V and propidium iodide, the apoptotic activity of Gratiola officinalis extract at a concentration of $0.88 \mathrm{mg} / \mathrm{ml}$ in respect of SK-BR-3 cells were in good agreement with the data obtained at Hoechst staining. Thus, if flow cytometry revealed $96.3 \%$ of late apoptotic cells, Hoechst staining revealed $86.3 \%$ of cells in apoptosis.

\subsection{Analysis of autophagic activity of Gratiola officinalis extract in cell line of human kidney carcinoma A-498}

Cells of kidney carcinoma line A-498 were treated with Gratiola officinalis extract in different concentrations in two-fold dilution, ranging from $3.6 \mathrm{mg} / \mathrm{ml}: 3.6 ; 1.8 ; 0.9$; $0.45 ; 0.225 ; 0.113 ; 0.056 ; 0.028 ; 0.014 ; 0.007 ; 0.004$. Cells were stained with LC3 marker, cell nuclei were stained with Hoechst. As a result, the cells acquired a dull red glow when autophagosomes were formed. A bright scarlet glow 
appeared when autophagosomes were associated with lysosomes and the process of digestion took place (Fig. 3). Fig. 4 shows the induction of autophagy in human kidney carcinoma A-498 cells in the control and under the action of Gratiola officinalis extract in concentrations ranging from 0.028 to $0.45 \mathrm{mg} / \mathrm{ml}$.

In the control, the autophagy induction coefficient was 1, starting with the extract concentration of $0.004 \mathrm{mg} / \mathrm{ml}$, the autophagy induction coefficient increases, reaching a maximum at a concentration of $0.056 \mathrm{mg} / \mathrm{ml}$. When the concentration of the extract increased, the coefficient of induction of autophagy decreased and returned to the initial state (Fig. 3, Table 2).

The dependence of cells with autophagosomes and autophagolysosomes was generally linear; the distribution was normal: the maximum number of autophagolysosomes in kidney carcinoma cells was observed at $0.056 \mathrm{mg} / \mathrm{ml}$ extract concentration.

Muse Autophagy LC3-Antibody Based Kit revealed a dull red glow of cells when autophagosomes formed, and a bright scarlet glow when autophagosomes bound to lysosomes and the digestion started.

There is no unequivocal opinion in the literature on the significance of autophagy in tumor cells nowadays. Some authors have reported a better prognosis in patients with autophagosomes in tumor cells [37], but most researchers believe that LC3b expression is associated with an unfavorable prognosis [38-40]. All authors agree that autophagy can develop in tumor cells as a protective mechanism of the tumor cell in response to the treatment [38-41], as we prove in our study.

Thus, we demonstrate that there is an activation of autophagy in kidney carcinoma cells under the action of low concentrations of Gratiola officinalis extract, which explains the mechanism of its cytoprotective activity that we also found in an experiment on SK-BR-3 breast carcinoma cells.

The increase in the number of living SK-BR-3 cells was observed under the influence of extract in $0.0352 \mathrm{mg} / \mathrm{ml}$ concentration. The significant increase in autophagy in A-498 cells was observed after incubation with extract within the range concentrations from 0.028 to $0.45 \mathrm{mg} / \mathrm{ml}$. The maximum number of autophagolysosomes was observed in kidney carcinoma cells after incubation with extract in $0.056 \mathrm{mg} / \mathrm{ml}$ concentration. Whereas after extract exposure in 0.88 $\mathrm{mg} / \mathrm{ml}$ concentration, no increase in autophagosome formation was detected (Table 2), but apoptosis was pronounced (Fig. 1).

Induction of autophagy at low concentrations of the extract, on the one hand, indicates sensitivity of tumor cells of the A-498 line in response to exposure to G. officinalis extract.

Table 2 Percentage distribution of kidney carcinoma tumor cells (A-498) with autophagosomes after Gratiola officinalis extract exposure at different concentrations for $24 \mathrm{~h}$ according to flow cytometry

\begin{tabular}{|c|c|c|c|}
\hline $\begin{array}{l}\text { Concentration of } \\
\text { extract }(\mathrm{mg} / \mathrm{ml})\end{array}$ & $\begin{array}{l}\text { Mean Autophagy } \\
\text { Intensity }\end{array}$ & $\begin{array}{l}\text { Autophagy Induction } \\
\text { Ratio }\end{array}$ & Total of cells \\
\hline 0 (control) & $22.2 \pm 1.5$ & 1 & $739 \pm 41$ \\
\hline 3.6 & $24.3 \pm 2.3$ & 1.1 & $447 \pm 20 *$ \\
\hline 1.8 & $27.4 \pm 3.2 *$ & 1.2 & $479 \pm 24 *$ \\
\hline 0.9 & $25.8 \pm 2.1$ & 1.2 & $431 \pm 19 *$ \\
\hline 0.45 & $28.5 \pm 3.4 *$ & 1.3 & $585 \pm 28 *$ \\
\hline 0.225 & $25 \pm 1.7$ & 1.1 & $605 \pm 31 *$ \\
\hline 0.113 & $29.5 \pm 2.4$ & 1.3 & $707 \pm 38$ \\
\hline 0.056 & $50.3 \pm 4.8 *$ & 2.3 & $694 \pm 28$ \\
\hline 0.028 & $31.1 \pm 2.5^{*}$ & 1.4 & $699 \pm 25$ \\
\hline 0.014 & $25.5 \pm 1.9$ & 1.2 & $683 \pm 27$ \\
\hline 0.007 & $27.8 \pm 2.1 *$ & 1.3 & $657 \pm 23^{*}$ \\
\hline 0.004 & $25.8 \pm 1.8$ & 1.2 & $649 \pm 25 *$ \\
\hline
\end{tabular}

Note: Differences are significant between values of experimental and control groups at $(*) p<0.05$. 

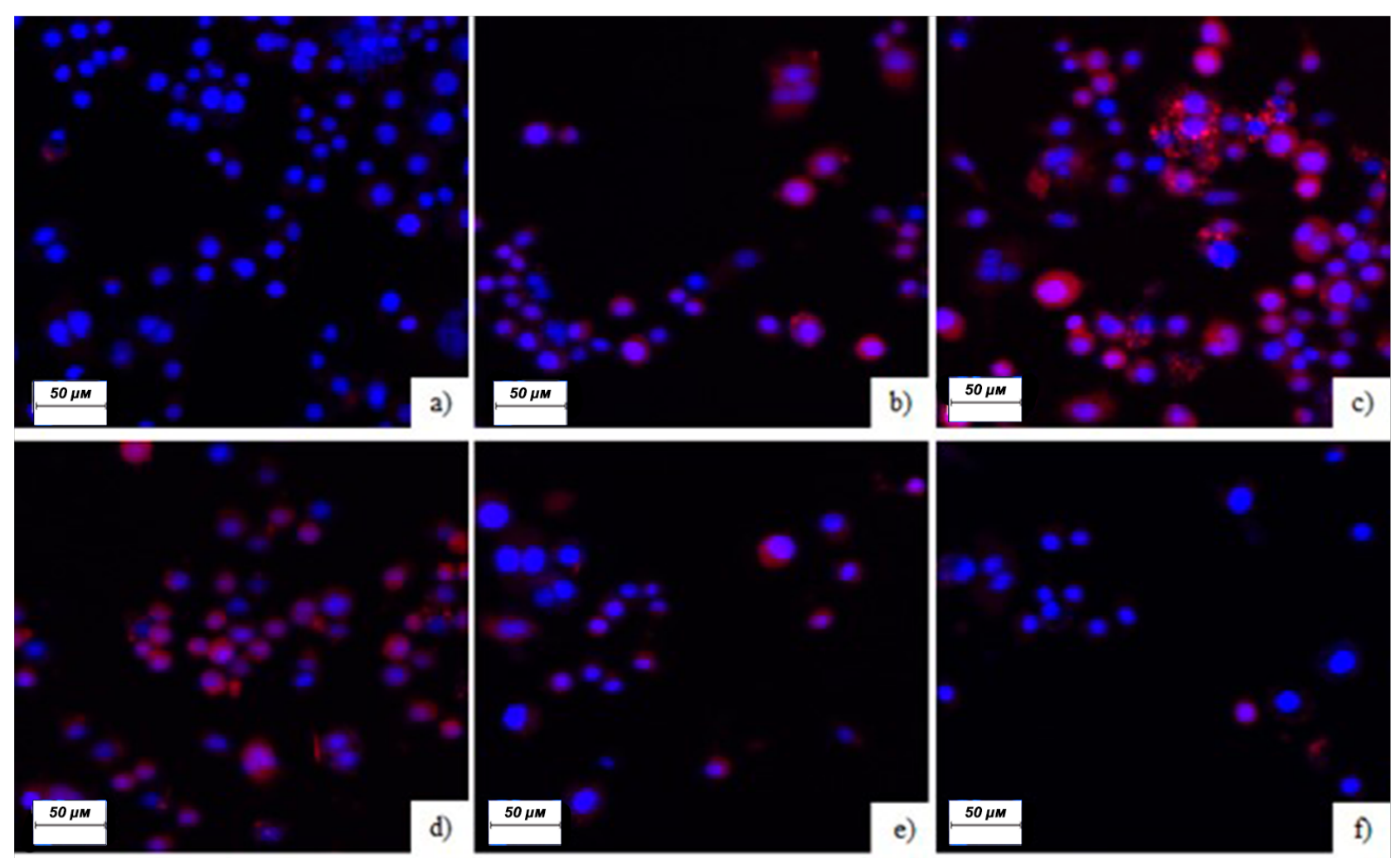

(A)
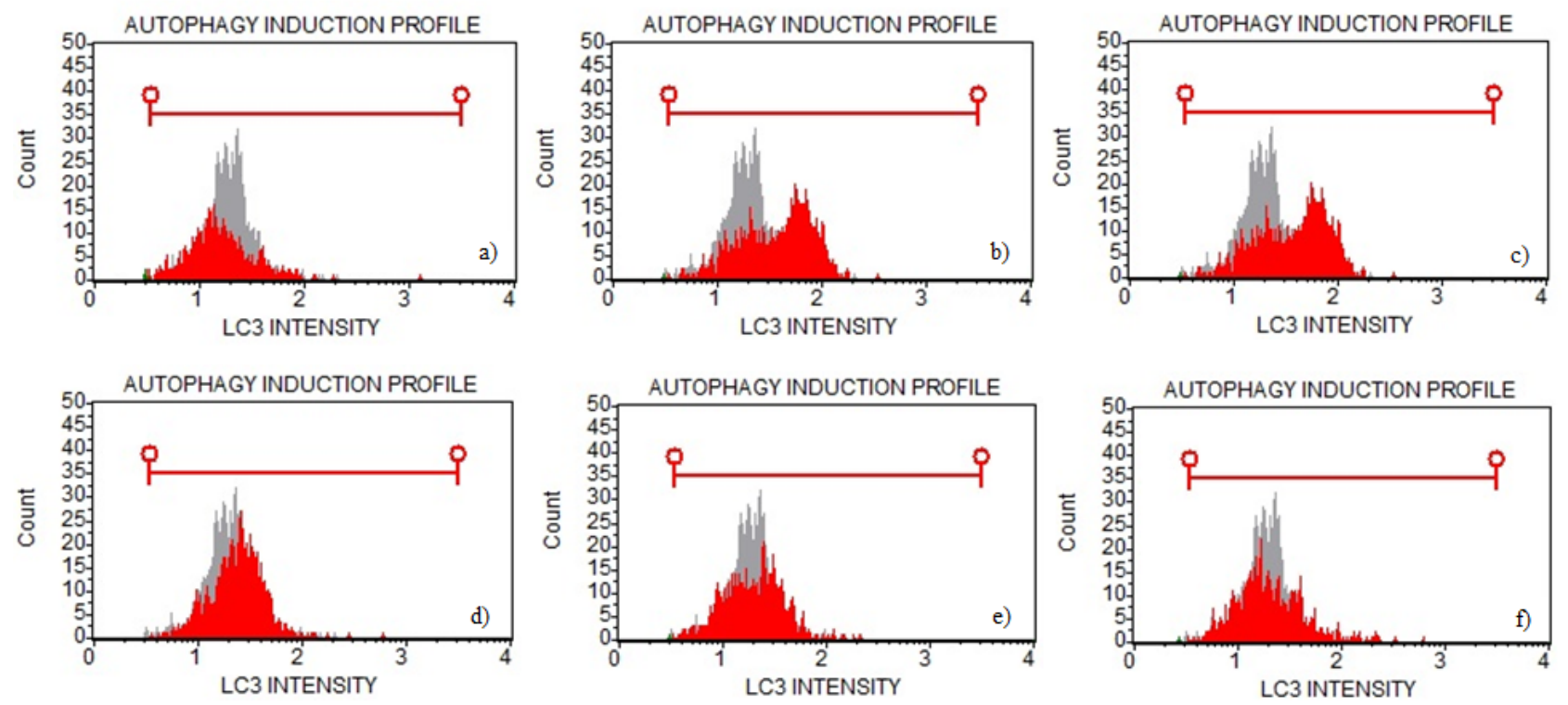

(B)

Fig. 3 Induction of autophagy in human kidney carcinoma cells A-498 in control and after Gratiola officinalis extract exposure in various concentrations a) control; b) the extract concentration was $0.028 \mathrm{mg} / \mathrm{ml}$ ), c) the extract concentration was $0.056 \mathrm{mg} / \mathrm{ml}$; d) the extract concentration was $0.113 \mathrm{mg} / \mathrm{ml}$; e) the extract concentration was $0.225 \mathrm{mg} / \mathrm{ml}$; f) the extract concentration was $0.45 \mathrm{mg} / \mathrm{ml}$. On the above (A) shows cells with double staining for LC3B protein (red and red) and Hoechst dye (blue color); below (B) - autophagosome induction after Gratiola officinalis extract exposure (flow cytometry results).

On the other hand, a cascade of events occurred: under the influence of low concentrations of the extract $(0.056 \mathrm{mg} / \mathrm{ml})$, cytoprotective autophagy was induced in the tumor cell, resulting in cell survival and resistance to exposure. However, at a higher concentration of $0.88 \mathrm{mg} / \mathrm{ml}$, activation of apoptosis occurred in kidney carcinoma cell culture. In our opinion, the cytoprotective 
autophagy is blocked at higher concentrations of the extract and cells die in a non-programmed way.

Activation of the mechanisms of autophagy, apoptosis, necrosis may occur under the influence of different components of the extract.

Thus, apigenin, described as component of the G. officinalis extract, is structurally related to the flavonoid Wogonin [4-6]. Wogonin is known to have an apoptotic effect on a wide range of human tumor cells in in vitro experiments and an inhibitory effect on tumor growth in vivo in various mouse tumor models [6-9, 41, 42]. Wogonin and structurally related natural flavones such as apigenin, chrysin and luteolin are inhibitors of cyclin-dependent kinase 9 (CDK9) and block-phosphorylation of the carboxy-terminal domain of RNA polymerase II in Ser(2). This effect leads to a decrease in ribonucleic acid synthesis, followed by rapid suppression of Mcl-1 and activation of apoptosis in tumor cell [4-6]. The G. officinalis extract causes tumor cell death and has no toxic effect on normal cells, that is similar with effects of the flavonoids in Scutellaria baicalensis Georgi extract, it has been demonstrated in both in vitro and in vivo experiments [6-9].

\section{Conclusion}

The antitumor effect of the G. officinalis extract has been shown on cell cultures of two human tumor lines: SK-BR-3 breast carcinoma and A-498 kidney carcinoma. The extract at concentration of $0.815 \mathrm{mg} / \mathrm{ml}$ causes apoptosis in half of the cells (AC50). However, in low concentration $(0.0352 \mathrm{mg} / \mathrm{ml})$, the extract has cytoprotective activity. This effect has a concentration dependence. The mechanism of cytoprotective activity of the extract in low concentrations is realized by activation of autophagy, which provides resistance of tumor cells to the therapeutic action. The maximum number of autophagosomes in carcinoma cells was observed at an extract concentration of $0.056 \mathrm{mg} / \mathrm{ml}$.

Thus, G. officinalis extract is a multicomponent flavonoid-containing composition, with a polyvalent effect, which form its "shrapnel" effect. The polyvalence of the therapeutic effect and the mutual potentiation of extract's effects with a proven broad spectrum of action is an undeniable advantage of this extract in complex chemotherapy. Detailed research should be continued to decipher and understand the mechanisms of antitumor activity of the individual components of the G. officinalis extract.

\section{Disclosures}

All authors declare that there is no conflict of interests in this paper.

\section{Acknowledgments}

The reported study was funded by project №SSMU-2021003 of Saratov State Medical University named after V. I. Razumovsky.

\section{References}

1. E. D. Goldberg, A. B. Syrkina, "Guidelines for the preclinical study of agents with the ability to inhibit the process of metastasis and increase the effectiveness of cytostatic therapy of malignant tumors," in The Guidelines for experimental (preclinical) study of new pharmacological substances, R.U. Khabriev (Ed.), Meditsina, Moscow (2005). ISBN: 5-225-04219-8.

2. D. B. Korman, "Targets and mechanisms of anticancer drugs," Practical Medicine, 333 (2014).

3. V. M. Perelmuter, M. V. Zavjalova, S. V. Vtorushin, E. M. Slonimskaya, and O. V. Savenkova, "Association between the morphologic heterogeneity of infiltrating ductal breast carcinoma and various forms of tumor progression," Siberian Journal of Oncology 3, 58-64 (2007).

4. G. Polier, J. Ding, B. V. Konkimalla, D. Eick, N. Ribeiro, R. Köhler, M. Giaisi, T. Efferth, L. Desaubry, P. H. Krammer, and M. Li-Weber, "Wogonin and related natural flavones are inhibitors of CDK9 that induce apoptosis in cancer cells by transcriptional suppression of Mcl-1," Cell death \& disease 2(7), e182 (2011).

5. D. Patel, S. Shukla, and S. Gupta, "Apigenin and cancer chemoprevention: progress, potential and promise (review)," International Journal of Oncology 30(1), 233-245 (2007).

6. G. Seelinger, I. Merfort, U. Wolfle, and C. M. Schempp, "Anti-carcinogenic effects of the flavonoid luteolin," Molecules 13(10), 2628-2651 (2008).

7. C. F. Tsai, W. L. Yeh, S. M. Huang, T. W. Tan, and D. Y. Lu, "Wogonin induces reactive oxygen species production and cell apoptosis in human glioma cancer cells," International Journal of Molecular Sciences 13(8), 9877-9892 (2012).

8. H. Chung, Y. M. Jung, D. H. Shin, J. Y. Lee, M. Y. Oh, H. J. Kim, K. S. Jang, S. J. Jeon, K. H. Son, and G. Kong, "Anticancer effects of wogonin in both estrogen receptor-positive and -negative human breast cancer cell lines in vitro and in nude mice xenografts," International Journal of Cancer 122(4), 816-822 (2008).

9. M. Li-Weber, "New therapeutic aspects of flavones: the anticancer properties of Scutellaria and its main active constituents wogonin, baicalein and baicalin," Cancer Treatment Reviews 35(1), 57-68 (2009).

10. J. Peng, Q. Qi, Q. You, R. Hu, W. Liu, F. Feng, G. Wang, and Q. Guo, "Subchronic toxicity and plasma pharmacokinetic studies on wogonin, a natural flavonoid, in Beagle dogs," Journal of Ethnopharmacology 124(2), 257-262 (2009). 
11. D. Bown, Encyclopaedia of Herbs and their Uses. The Royal Horticultural Society, Dorling Kindersley Limited, London, UK (1995).

12. E. Launert, Edible and Medicinal Plants, Hamlyn, London (1981).

13. M. Zia-Ul-Haq, A. Kausar, S. A. Shahid, M. Qayum, S. Ahmad, and I. Khan, "Phytopharmacological profile of Gratiola officinalis Linn.: A review," Journal of Medicinal Plants Research 6(16), 3087-3092 (2012).

14. M. Ahmad, N. Muhammad, J. Mehjabeen, N. Jahan, M. Ahmad, and S. Habib, "Pharmacological and biological evaluation of extracts from Gratiola officinalis L. (Scrophulariaceae)," Pakistan Journal of Pharmaceutical Sciences 25(3), 657-663 (2012).

15. N. Muhammad, M. Ahmad, Mehjabeen, N. Jahan, M. Ahmad, and Z. Khan, "Spasmogenic and spasmolytic activity of Gratiola officinalis Linn,” International Journal of Biology, Pharmacy and Allied Sciences 1(5), 636-644 (2012).

16. J. Lust, The Herb Book, Bantam Books, USA (1974).

17. G. Graves, Medicinal Plants, Bracken Books, Randam House, London (1996).

18. L. Ali, T. S. Rizvi, M. Ahmad, and F. Shaheen, "New iridoid glycoside from Gratiola officinalis (Scrophulariaceae)," Journal of Asian Natural Product Research 14(12), 1191-1195 (2012).

19. S. Boryczka, E. Bebenek, M. Jastrzebska, J. Kusz, and M. Zubko, "Crystal structure of betulinic acid-DMSO solvate," Zeitschrift für Kristallographie 227(6), 379-384 (2012).

20. J. Rothenburger, E. Haslinger, "Caffeic acid glycoside esters from Gratiola officinalis L," Liebigs Annalen der Chemie 11, 1113-1115 (1994).

21. R. J. Grayer-Barkmeijer, F. A. Tomas-Barberan, "8-Hydroxylated flavone-O-glycosides and other flavonoids in chemotypes of Gratiola officinalis," Phytochemistry 34(1), 205-210 (1993).

22. S. Kumar, A.K. Pandey, "Chemistry and Biological Activities of Flavonoids: An Overview," The Scientific World Journal 2013, 162750 (2013).

23. T. Rudolf, H. Annemarie, and U. Triterpene, "Gratiosid, ein Triterpenglykosid aus Gratiola officinalis L," Berichte der deutschen chemischen Gesellschaft Weinheim 85 (11), 1067-1077 (1952).

24. L. I. Borodin, V. I. Litvinenko, and N. V. Kurinnaya, "New flavonoid C-glycosides from Gratiola officinalis," Chemistry of Natural Compounds 6(1), 19-24 (1970).

25. V. I. Litvinenko, L. I. Borodin, and N. V. Kurinnaya, "Apigenin and its glycosides from Gratiola officinalis," Chemistry of Natural Compounds 5(4), 328-329 (1969).

26. N. V. Polukonova, N. A. Durnova, M. N. Kurchatova, N. A. Navolokin, and A. G. Golikov, "Chemical analysis of the new biological active composition from medicative herb hedge-hissop (Gratiola Officinalis L.)," Khimija Rastitel'nogo Syr'ja 4, 165-173 (2013) [in Russian].

27. N. A. Navolokin, A. V. Ivlichev, D. A. Mydrak, and G. A. Afanasjeva, "Influence of flavonoid-containing extract (Gratiola Officinalis L.) on the content of vitamin E and intensity of peroxidation processes in the blood of rats with transplanted liver cancer PC-1," Eksperimental'naya i Klinicheskaya Farmakologiy 80(10), 40-43 (2017) [in Russian].

28. N. A. Navolokin, D. A. Mydrak, N. V. Polukonova, and A. B. Bucharskaya, "Effects of Gratiola Officinalis L. extract containing flavonoids on pathomorphism of inoculated renal cancer in rats," Eksperimental'naya i Klinicheskaya Farmakologiy 80(6), 19-23 (2017) [in Russian].

29. N. A. Navolokin, D. A. Mydrak, N. V. Polukonova, and S. A. Tychina, "Evaluation of the antitumor and anticachexia activity of Gratiola Officinalis L. extract in rats with transplanted sarcoma," Siberian Journal of Oncology 5(1), 3743 (2016) [in Russian].

30. N. V. Polukonova, N. A. Durnova, and N. N. Khakhulina, "Phytocenoses Gratíola Officinális L., productivity and its inventories of raw materials in the islands chardymskogo r. Volga Saratov region," Bulletin of the Botanical Garden of the Saratov State University 14(2), 56-61 (2016) [in Russian].

31. N. V. Polukonova, N. A. Navolokin, and S. V. Raykova, "Anti-inflammatory, antipyretic and antimicrobial activity flavonoid-containing extract of Gratiola officinalis L,” Eksperimental'naya i Klinicheskaya Farmakologiy 78(1), 3438 (2015).

32. N. V. Polukonova, M. N. Kurchatova, N. A. Navolokin, A. B. Bucharskaya, N. A. Durnova, and G. N. Maslyakova, "A new extraction method of bioflavanoids from poisonous plant," Russian Open Medical Journal 3(3), 304 (2014).

33. N. A. Navolokin, D. A. Mydrak, A. B. Bucharskaya, O. V. Matveeva, S. A. Tychina, N. V. Polukonova, and G. N. Maslyakova, "Effect of flavonoid-containing extracts on the growth of transplanted sarcoma 45, peripheral blood and bone marrow condition after oral and intramuscular administration in rats," Russian Open Medical Journal 6(3), 304 (2017).

34. N. V. Tkachenko, E. V. Bykova, A. B. Pravdin, N. A. Navolokin, N. V. Polukonova, A. B. Bucharskaya, D. A. Mudrak, and A. Y. Prilepskii, "Comparison of membrane-protective activity of antioxidants quercetine and Gratiola officinalis L. extract under conditions of photodynamic haemolysis," Proceedings of SPIE 9917, 99170L (2016).

35. N. A. Navolokin, N. V. Polukonova, G. N. Maslyakova, A. B. Bucharskaya, and N. A. Durnova, "Effect of extracts of Gratiola officinalis and Zea mays on the tumor and the morphology of the internal organs of rats with trasplanted liver cancer," Russian Open Medical Journal 1(2), 0203 (2012). 
36. A. Mylnikov, N. Navolokin, D. Mudrak, N. Polukonova, A. Bucharskaya, and G. Maslyakova, "Tumor cell death visualization of renal cell carcinoma under the combined effect of the Gratiola officinalis extract and cyclophosphamide using fluorescent staining methods," Journal of Innovative Optical Health Sciences 14(05), 2142004 (2021).

37. Z. Yang, R. A. Ghoorun, X. Fan, P. Wu, Y. Bai, and J. Li, "High expression of Beclin-1 predicts favorable prognosis for patients with colorectal cancer," Clinics and Research in Hepatology and Gastroenterology 39(1), 98-106 (2015).

38. J. Y. Tang, E. Hsi, Y. C. Huang, N. C. Hsu, P. Y. Chu, and C. Y. Chai, "High LC3 expression correlates with poor survival in patients with oral squamous cell carcinoma," Human Pathology 44(11), 2558-2562 (2013).

39. J. L. Liu, F. F. Chen, J. Lung, C. H. Lo, F. H. Lee, and Y. C. Lu, "Prognostic significance of p62/SQSTM1 subcellular localization and LC3B in oral squamous cell carcinoma," British Journal of Cancer 111(5), 944-954 (2014).

40. K. Lai, S. Matthews, J. S. Wilmott, M. C. Killingsworth, J. L. Yong, N. J. Caixeiro, J. Wykes, A. Samakeh, D. Forstner, M. Lee, J. McGuinness, N. Niles, A. Hong, A. Ebrahimi, and C. S. Lee, "Differences in LC3B expression and prognostic implications in oropharyngeal and oral cavity squamous cell carcinoma patients," BMC Cancer 18, 624 (2018).

41. D. H. Wu, C. C. Jia, J. Chen, Z. X. Lin, D. Y. Ruan, and X. Li, “Autophagic LC3B overexpression correlates with malignant progression and predicts a poor prognosis in hepatocellular carcinoma," Tumor Biology 35(12), 1222512233 (2014).

42. W. Wang, Q. L. Guo, Q. D. You, K. Zhang, Y. Yang, and J. Yu, “The anticancer activities of wogonin in murine sarcoma S180 both in vitro and in vivo," Biological and Pharmaceutical Bulletin 29(6), 1132-1137 (2006).

43. S. Baumann, S. C. Fas, M. Giaisi, W. W. Muller, A. Merling, and K. Gulow, "Wogonin preferentially kills malignant lymphocytes and suppresses T-cell tumor growth by inducing PLCgamma1 - and Ca2+-dependent apoptosis," Blood, The Journal of the American Society of Hematology 111(4), 2354-2363 (2008). 